\title{
Fazla Kilo Riski Olan Çocuklarda Vitamin D Düzeylerinin
} Değerlendirilmesi

\author{
Evaluation of Vitamin D levels in Children at Risk of Being Overweight
}

Beril Aydın', Sıdıka Songül Yalçın

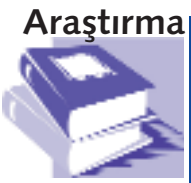

Research
DOI: $10.17942 /$ sted.811649

Öz

Amaç: Bu çalışmada fazla kilo riski olan beş yaş altı çocuklarda vitamin D düzeylerinin incelenmesi amaçlanmıştır.

Yöntem: Başkent Üniversitesi Genel Pediatri Polikliniğ'ine Şubat 2019-Mart 2019tarihleri arasında sağlam çocuk kontrolleri için başvuran ve kontrollerinde serum 25 hidroksi vitamin D [25(OH)D] düzeyi bakılan beş yaş altı 290 çocuk çalışmaya alındı. Yaşa göre beden kitle indeksinin (BAZ) Z skorları hesaplanarak normal ve fazla kilo riski olarak olgular iki gruba ayrıldı. Serum $25(\mathrm{OH})$ D düzeyi $\leq 20 \mathrm{ng} / \mathrm{ml}$ olanlar vitamin D eksik, 21-29 $\mathrm{ng} / \mathrm{ml}$ olanlar vitamin D yetersiz, $\geq 30 \mathrm{ng} / \mathrm{ml}$ olanlar vitamin D yeterli kabul edildi. Serum 25(OH)D düzeyleri her iki grupta karşılaştırıldı.

Bulgular: Çalışmamızda serum $25(\mathrm{OH}) \mathrm{D}$ düzeyi (ort $\pm \mathrm{SH}$ ) normal kilolu grupta $21.9 \pm 0.7 \mathrm{ng} / \mathrm{ml}$ iken, fazla kilo riski olan grupta $15.9 \pm 1.1 \mathrm{ng} / \mathrm{ml}$ idi. Serum 25(OH)D düzeyi açısından her iki grup arasında istatistiksel olarak anlamlı fark saptandı $(p<0.001)$. Normal kilolu grupta serum 25(OH)D düzeyi $<10$ $\mathrm{ng} / \mathrm{ml}$ olan \% $14.7 \mathrm{olgu}, 10-19 \mathrm{ng} / \mathrm{ml}$ olan $\% 35.9$ olgu $20-29 \mathrm{ng} / \mathrm{ml}$ olan $\% 29.4$ olgu ve $\geq 30 \mathrm{ng} / \mathrm{ml}$ olan \% 19.9 olgu vardı. Fazla kilo riski olan grupta ise serum 25(OH)D düzeyi $<10 \mathrm{ng} / \mathrm{ml}$ olan $\% 20.3$ olgu, $10-19 \mathrm{ng} / \mathrm{ml}$ olan $\% 61 \mathrm{olgu}, 20-29 \mathrm{ng} / \mathrm{ml}$ olan $\% 11.9$ olgu ve $\geq 30 \mathrm{ng} / \mathrm{ml}$ olan $\% 6.8$ bulunmaktaydı.

Sonuç: Çalışmamız fazla kilo riski olan çocuklarda serum $25(\mathrm{OH})$ D düzeyinin düşük olduğunu göstermektedir. Sonuçlarımız fazla kilo riski olan çocuklar ve normal kilolu çocuklarda yeterli vitamin D seviyelerinin yakalanabilmesi için gerekli taramaların yapılmasının gerekli olduğunu göstermektedir.

Anahtar sözcükler: Vitamin D eksikliği, Fazla kilo riski olan çocuklar, Obezite, Beden kitle indeksi
Geliş/Received

02.04 .2020

Kabul/Accepted

\begin{abstract}
Objective: This study aimed to assess vitamin D levels among the children, under 5 years of age, having the risk of being overweight.
\end{abstract}

Methods: 290 children under 5 years of age, who visited Baskent University General Pediatrics Outpatient Clinic between February 2019 and March 2019 for well-child check-up and whose serum 25-hydroxy vitamin D [25(OH)D] levels have been examined, were included in the study. The children were divided into two groups according to body mass index (BMI) Z-scores by age: normalweight children and those having the risk of being overweight. The serum $25(\mathrm{OH}) \mathrm{D}$ levels of $\leq 20$ $\mathrm{ng} / \mathrm{ml}, 21-29 \mathrm{ng} / \mathrm{ml}$ and $\geq 30 \mathrm{ng} / \mathrm{ml}$ were considered vitamin D deficiency, insufficiency and sufficiency, respectively. Serum 25(OH)D levels were compared in both groups.

Findings: In our study, the serum 25(OH)D level (mean $\pm \mathrm{SE}$ ) was $21.9 \pm 0.7 \mathrm{ng} / \mathrm{ml}$ in the normalweight group, while it was $15.9 \pm 1.1 \mathrm{ng} / \mathrm{ml}$ in the group with the risk of being overweight. There was a statistically significant difference between the two groups in terms of serum $25(\mathrm{OH}) \mathrm{D}$ level $(\mathrm{p}<0.001)$. Of the cases in normal-weight group, $14.7 \%$, $35.9 \%, 29.4 \%$ and $19.9 \%$ had a serum $25(\mathrm{OH}) \mathrm{D}$ level of $<10 \mathrm{ng} / \mathrm{ml}, 10-19 \mathrm{ng} / \mathrm{ml}, 20-29 \mathrm{ng} / \mathrm{ml}$ and $\geq 30 \mathrm{ng} / \mathrm{ml}$, respectively. As for the group with the risk of being overweight, of the cases, $20.3 \%, 61 \%$, $11.9 \%$ and $6.8 \%$ had a serum $25(\mathrm{OH}) \mathrm{D}$ level of $<10 \mathrm{ng} / \mathrm{ml}, 10-19 \mathrm{ng} / \mathrm{ml}, 20-29 \mathrm{ng} / \mathrm{ml}$ and $\geq 30$ $\mathrm{ng} / \mathrm{ml}$, respectively.

Conclusion: Our study reveals that the serum 25(OH)D levels are low in children at the risk of being overweight. Our results show that necessary screening should be carried out to achieve adequate vitamin $D$ levels in children who are at risk of being overweight and in normal-weight children.

Key words: Vitamin D deficiency, Children at risk of being overweight, Obesity, Body Mass Index

1 Dr.; Öğr. Üyesi, Başkent Ü. Tıp Fak. Çocuk Sağlığı ve Hast. AD, Ankara (Orcid No: 0000-0002-9646-9377)

2 Prof. Dr.; Hacettepe Ü. Tıp Fak. Çocuk Sağlığı ve Hast. AD, Ankara (Orcid No: 0000-0001-9061-4281) 


\section{Giriş}

Vitamin D, yağda çözünen ve depolanabilen vitamin grubunda olup hormon benzeri birçok göreve sahiptir (1). Vitamin $D$ reseptörü nükleer steroid reseptör grubundan olup inflamasyon ve immüno modülasyon ile ilgili çok sayıda genin transkripsiyonunu da düzenlemektedir (2). Vitamin D araștırmalarındaki son gelişmeler, kas-iskelet sistemi yanında birçok vücut sistemi üzerinde de etkili olduğunu göstermektedir (3). Vitamin D yetersizliğinin kanser, diyabetes mellitus, multipl skleroz gibi otoimmün hastalıklarla ve kardiyovasküler hastalıklar, obezite ve şizofreni gibi hastalıklarla ilişkili olduğunu bildiren yayınlar mevcuttur (4). Vitamin D, glikoz homeostazı, insülin salgılama mekanizmaları ve obezite ile ilişkili inflamasyonun düzenlenmesinde önemli bir rol oynamaktadır (5). Obezite ile vitamin $\mathrm{D}$ bağlantısı üzerine etkili proteinler olduğunu gösteren genetik çalışmaların yanı sıra oksidatif stres, inflamasyon ve hücre metabolizmasındaki bozuklukların da rol oynadığı gösterilmiştir (6).

Çocukluk çağı obezitesi özellikle gelişmiş ülkelerde olmakla birlikte, bütün dünyada artan bir prevalansa sahiptir. Artan obezite sıklığı, obeziteye bağlı komplikasyonların daha sık ve daha erken yaşlarda görülmesine yol açmıştır Yetişkinlerde yapılan çalışmada düşük serum 25 $(\mathrm{OH})$ düzeyinin kişiyi obeziteye yatkın hale getirdiği, normal kilolu kişilere kıyasla daha fazla kilo artışı ile ilişkili olduğu gösterilmiştir (7). Çocuklarda da vitamin D eksikliğinin obezitede arttığı çalışmalarda gösterilmiştir (8). Obezitede görülen vitamin $D$ eksikliği nedenleri arasında artmış yağ dokusunun yüksek oranda vitamin $D$ depolaması da nedenler arasında yer almaktadır (9).

Fazla kilo riski olan beş yaş altı çocuklarda serum $25(\mathrm{OH})$ D düzeyi ile ilgili yapılmış sınırlı sayıda araştırma mevcuttur. Bu çalışmada fazla kilo riski olan çocuklar ile sağlıklı kontroller arasında serum $25(\mathrm{OH}) \mathrm{D}$ düzeylerinin karşılaştırılması amaçlandı.

\section{Gereç ve Yöntem}

Çalışmamızda retrospektif olarak Başkent Üniversitesi Ankara Hastanesi Genel Pediatri Bölümüne Şubat 2019- Mart 2019 tarihleri arasında sağlam çocuk kontrolleri için başvurmuş ve serum $25(\mathrm{OH})$ D düzeyi bakılmış beş yaş altında 290 çocuk alınmıştır. Olguların demografik verilerine, antropometrik ölçümlerine ve serum vitamin D düzeylerine hasta kayıtlarından ulaşıldı. Olguların kullandıkları vitamin D içermeyen vitamin ya da takviye edici gıdalar kullanılan vitamin olarak kaydedildi. Yaşamın ilk bir yılı verilen vitamin D proflaksisi alan çocuklar vitamin D tedavisi alanlar kapsamında değerlendirilmeyerek çalışmaya dahil edildi. Kronik hastalığı bulunanlar, son bir yıl içinde vitamin D tedavisive herhangi bir farmakolojik tedavi alanlar çalışmaya dahil edilmedi.

Kilo ve boy ölçümleri kalibrasyonları yapılmış dijital bir tartı aleti ve Harpendenstadio metre kullanılarak yapıldı. Beden kitle indeksi (BKi) vücut ağırlığı $(\mathrm{kg}) /$ boy $\left(\mathrm{m}^{2}\right)$ formülüyle hesaplandı. Yaşa göre beden kitle indeksinin (BAZ) Z skorlarının hesaplanmasında WHO2OO6 programı kullanılmış, normal ve fazla kilolu riski olarak olgular gruplandırıldı (10). Fazla kilo riski olan çocukları tanımlamak için Dünya sağlık Örgütü (DSÖ)'nün beş yaş altı çocuklarda fazla kilo riski tanımı için belirlediği 1-2 SD arası ya da 85-95 yüzdeliğin arası ve normal kilo tanımı için belirlediği 15-85. yüzdeliğin arası ölçütleri esas alındı $(10,11)$.

Serum $25(\mathrm{OH})$ D seviyesi, kemilüminesant mikropartikül immüno analiz (Abbott Architect 12000 analizörü) kullanılarak analiz edildi. Architect 25-OH D Vitamini tayini, $\leq 10.0$ $\mathrm{ng} / \mathrm{ml}$ 'lik bir Limit Saptama Sınırına (LoD) sahip olacak biçimde tasarlandı. Serum $25(\mathrm{OH}) \mathrm{D}$ düzeyi $<10 \mathrm{ng} / \mathrm{ml}$ olan çocuklar ciddi vitamin $D$ eksik, $10-19 \mathrm{ng} / \mathrm{ml}$ olan çocuklar vitamin D eksik, 20-29 ng/ml olanlar vitamin D yetersiz, $\geq 30 \mathrm{ng} /$ $\mathrm{ml}$ olanlar vitamin $\mathrm{D}$ yeterli olarak kabul edildi (12).

Çalışma, Helsinki Bildirgesi'nde belirtilen ilkelere uygun olarak hazırlanmış ve Başkent Üniversitesi Kurumsal İnceleme Kurulu (Proje no: KA20 / 213) tarafından onaylanmıştır.

\section{İstatistiksel değerlendirme}

İstatiksel analiz SPSS25. 0 yazılım programı (Chicago, IL) kullanılarak yapıldı. Dağılımların normalliği Kolmogorov- Smirnov testine dayandırıldı. Normal dağılımda bağımsız gruplar için "student t test" kullanıldı. Çalışma gruplarına ait veriler, yalnızca ilgili olduğu grubun özelliğini 
gösteriyorsa "ortalama \pm standart sapma" olarak verildi. Verileri birbiri ile karşılaştırmada ise, gruplar arasında fark olup olmadığını öğrenmek için "ortalama \pm standart hata" olarak verildi. Dağılımın normal olmadığı bağımsız gruplar için "Mann Whitney U test" kullanıldı, ortanca, altüst dörtte birlik kesim değerleri verildi. Gruplarda yüzde dağılımları "Chi-kare testi" ile incelendi. Vitamin D ile değişkenler arasındaki ilişki "Spearman korelasyon testi" ile gösterildi. Generalizedlinear model ile yaş ve cins kontrol edilerek vitamin $\mathrm{D} p<0.05$ anlamlı kabul edildi.

\section{Bulgular}

Çocukların demografik verileri Tablo 1'de gösterildi. Toplam 290çocuğun yaş ortalaması normal kilolu olan grupta (ortalama \pm SS) 19. $5 \pm 7$.

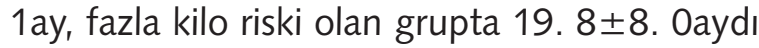
(Tablo 1). Çocukların 231'i (\% 79. 7) normal kilolu, 59'u (\% 20. 3) fazla kilo riski olan çocuklardı. Alerji öyküsü, ailede allerji öyküsü, olguların son bir yılda geçirdikleri alt solunum yolu enfeksiyon öyküsü her iki grupta benzerdi (Tablo 1).

Normal kilolu olan grupta olguların \% 34. 2'i, fazla kilo riski olan grupta \%11. 9'u vitamin kullanmaktaydı ve her iki grup arasında istatistiksel olarak anlamlı fark saptandı $(p=0$. 023) (Tablo 1). Vitamin $D$ ve yaşa göre beden kitle indeksinin (BAZ) z skoru arasında düşük derecede negatif korelasyon vardı $(r=-0.38$, p<0. 001).
Fazla kilo riski olan grup ile normal kilolu grupta kan hemoglobin, serum ferritin, vitamin B12 ve $25(\mathrm{OH}) \mathrm{D}$ düzeyleri Tablo 2'de gösterilmiştir. Kanhemoglobin, serum ferritin ve vitamin B12düzeyleri açısından her iki grup arasında fark yoktu (Tablo 2). Olguların yaş ve cinsiyeti kontrol edildiğinde fazla kilo riski olan grubun vitamin $\mathrm{D}$ düzeyi (ort $\pm \mathrm{SH}$ ) normal kilolu gruptan daha

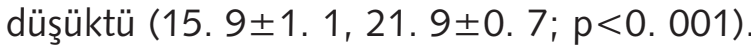

Normal kilolu grupta serum $25(\mathrm{OH}) \mathrm{D}$ düzeyi $<10$ $\mathrm{ng} / \mathrm{ml}$ olan \% 14.7 olgu, $10-19 \mathrm{ng} / \mathrm{ml}$ olan $\% 35$. 9 olgu $20-29 \mathrm{ng} / \mathrm{ml}$ olan $\% 29.4$ olgu ve $\geq 30$ $\mathrm{ng} / \mathrm{ml}$ olan \% 19. 9 olgu vardı (Tablo 2). Fazla kilo riski olan grupta ise serum $25(\mathrm{OH}) \mathrm{D}$ düzeyi $<10 \mathrm{ng} / \mathrm{ml}$ olan \%20. 3 olgu, $10-19 \mathrm{ng} / \mathrm{ml}$ olan $\% 61 \mathrm{olgu}, 20-29 \mathrm{ng} / \mathrm{ml}$ olan \%11. 9 olgu ve $\geq 30 \mathrm{ng} / \mathrm{ml}$ olan \%6. 8 bulunmaktaydı (Şekil 1). Fazla kilolu olan grupta vitamin D düzeyinin 20 $\mathrm{ng} / \mathrm{ml}$ ve üstünde olma sıklığının normal kilolu olgulara göre daha düşük olduğu görüldü $(p<0.001$, Tablo 2)

\section{Tartışma}

Çalışmamızda fazla kilo riski olan çocuklarda normal kilolu çocuklara kıyasla serum $25(\mathrm{OH}) \mathrm{D}$ düzeyinin düşük olduğu ve vitamin D eksikliği görülme sıklığının daha yüksek görüldü.

Çalışmamızda fazla kilo riski olan çocuklarda vitamin D yeterliliği \% 18.7, normal ağırlıklı çocuklarda ise \% 49.3'dir. Bu sonuç, aşırı kilolu çocuklarda serum vitamin D eksikliğinin sık

Tablo 1. Olguların demografik özellikleri

\begin{tabular}{|c|c|c|c|}
\hline & $\begin{array}{c}\text { Normal } \\
\text { kilolu grup } \\
n=231\end{array}$ & $\begin{array}{c}\text { Fazla kilo riski } \\
\text { olan grup } \\
n=59\end{array}$ & p \\
\hline Yaş (ay), ortalama \pm SS & 19. $5 \pm 7.1$ & 19. $8 \pm 8.0$ & 0.823 \\
\hline Erkek cinsiyet, \% & 52. 4 & 45.8 & 0. 364 \\
\hline Yaşa göre ağırlık z skoru, WAZ, ortalama \pm SS & $0.43 \pm 0.89$ & 1. $31 \pm 0.85$ & $<0.001$ \\
\hline Yaşa göre boy z skoru, HAZ, ortalama $\pm S S$ & $0.53 \pm 1.29$ & $0.32 \pm 1.68$ & 0.306 \\
\hline Boya göre ağırlık z skoru, WHZ, ortalama \pm SS & $0.24 \pm 0.53$ & 1. $60 \pm 0.60$ & $<0.001$ \\
\hline Yaşa göre vücut kitle indeksi z skoru, BAZ,ortalama \pm SS & $0.19 \pm 0.47$ & 1. $62 \pm 0.76$ & $<0.001$ \\
\hline Ailede allerji öyküsü, \% & 51. 1 & 64.4 & 0.067 \\
\hline Çocukta alerjik hastalık öyküsü, \% & 45. 5 & 32. 2 & 0.066 \\
\hline Son 1 yılda ASYE öyküsü, \% & 14. 7 & 20. 3 & 0. 292 \\
\hline Vitamin kullanımı* $\%$ & 34.2 & 11. 9 & 0.001 \\
\hline
\end{tabular}

SS: standart sapma

ASYE alt solunum yolu enfeksiyon

*Vitamin D içermeyen retrospektif olarak kayıtlardan ulaşılan balık yağı, çinko, c vitamini ve takviye edici gıda içerikli olan ürünlerdir 


\begin{tabular}{|c|c|c|c|c|}
\hline & & $\begin{array}{c}\text { Normal kilolu } \\
\text { grup } \\
n=231\end{array}$ & $\begin{array}{c}\text { Fazla kilo riski } \\
\text { olan grup } \\
n=59\end{array}$ & $\mathrm{p}$ \\
\hline Kan hemoglobin, g/dl & ortalama $\pm S S$ & $12.8 \pm 1.4$ & $13.1 \pm 1.1$ & 0.076 \\
\hline Lökosit & ortalama \pm SS & $9.6 \pm 3.8$ & $9.2 \pm 4.4$ & 0.544 \\
\hline Trombosit & ortalama \pm SS & $310 \pm 81$ & $307 \pm 95$ & 0.798 \\
\hline CRP ortanca (25-75p) & $1.2(0.4-5.6)$ & $1.2(0.7-4.6)$ & 0.511 & \\
\hline Serum ferritin, ng/ml & ortanca (25-75p) & $32.5(19.9-54.3)$ & $37.5(20.6-64.0)$ & 0.450 \\
\hline Serum ferritin $<20 \mathrm{ng} / \mathrm{ml}$ & $\%$ & 25.7 & 21.1 & 0.471 \\
\hline Serum vitamin B12, pg/ml & ortanca (25-75p) & $355(245-586)$ & $370(254-498)$ & 0.652 \\
\hline Serum vitamin B12<300pg/ml & $\%$ & 42.4 & 37.3 & 0.475 \\
\hline Serum 25(OH)D düzeyi & ortanca (25-75p) & $19.7(13.3-26.7)$ & $15.4(10.4-19.1)$ & $<0.001$ \\
\hline Serum 25(OH)D düzeyi* & ortalama $\pm \mathrm{SH}$ & $21.9 \pm 0.7$ & $15.9 \pm 1.1$ & $<0.001$ \\
\hline Serum 25(OH)D düzeyi & $\%$ & & & $<0.001$ \\
\hline$<20 \mathrm{ng} / \mathrm{ml}$ & & 50.6 & 81.4 & \\
\hline$\geq 20 \mathrm{ng} / \mathrm{ml}$ & & 49.4 & 18.6 & \\
\hline
\end{tabular}

SS: standart sapma

SH: Standart hata

* generalizedlinear model, yaş ve cins ile kontrol edilerek.

olduğunu gösteren ülkemizde yapılan önceki çalışmalarla benzerdir $(13,14)$.

Son yıllarda yapılan yayınlarda vitamin D eksikliğinin kilo fazlalığı derecesi ve BKi ile ilişkili olduğu, ancak atta yatan mekanizmanın net olmadığı gösterilmiştir (15). Vitamin D reseptörününinsan yağ dokusunda bulunması nedeniyle, yağ dokusunun vitamin D için hedef organı olabileceğini düşündürmektedir (13). Fazla kilo riski olan çocuklarda artmış yağ dokusunun yüksek oranda vitamin $\mathrm{D}$ depolaması, vitamin $\mathrm{D}$ biyoyararlanımını azaltarak serum $25(\mathrm{OH}) \mathrm{D}$ düzeyini düşürebilmektedir (16). Ayrıca vitamin D eksikliğinde artan paratiroid hormonun yağ hücrelerine kalsiyum akışına neden olarak yağlanmayı artırdığı da bildirilmiştir (17). Kurşun ve ark. yaptıkları çalışmada, obez çocuklarda vitamin D eksikliğinin \% 28.1 oranında olduğunu, obez olmayan gruba göre daha yüksek oranda vitamin $D$ eksikliği görüldüğünü bildirmişlerdir (18). Fazla kilolu ve obez çocuklarda vitamin D düzeyleri ile ilgili yapılan bir çalışmada ise her iki grup arasında vitamin D eksikliği açısından fark saptanmadığı bulunmuştur (13). Bizim çalışmamızda fazla kilo riski olan çocuklarda vitamin D yetersizliği oranının \%93. 2 olduğu saptanmıştır.
Bazı davranış biçimleri de fazla kilo riski olan çocuklarda serum $25(\mathrm{OH}) \mathrm{D}$ düzeyinin düşük olmasına neden olabilmektedir. Fazla kilo riski olan çocukların daha hareketsiz olmaları ve ev içinde daha fazla vakit geçirmeleri, güneş ışığına daha az maruz kalmalarına ve endojen vitamin $D$ sentezinde de azalmaya yol açabilmektedir (19). Fazla kilolu çocukların dengesiz beslenmeleri de vitamin eksikliklerinde rol oynayabilir. 2011 yılında Gazi Üniversitesi tarafından yapılan, Türkiye'de 6-17 aylık çocuklarda ve annelerinde vitamin $D$ düzeyi ve demir eksikliği anemisi durum belirleme ve yürütülen programların değerlendirilmesi araştırmasında 2,504 çocukta vitamin D eksikliği \% 26. 8 ve vitamin D yetersizliği \% 66. 7 olarak saptanmıştır (20). Çalışmamızda da benzer olarak sağlıklı çocuklarda vitamin D yetersizliği \% 50.6 bulunmuştur.

Aşırı kilolu ve fazla kilo riski olan çocuklarda vitamin $\mathrm{D}$ homeostazındaki değişiklikler nedeniyle (21), bu çocuklarda vitamin D yeterlilik ve yetersizlik durumunun tanımlanması önemlidir. Kilolu çocuklarda optimal serum vitamin D düzeyi ile ilgili yayınlar ise sınırlıdır. Vitamin D yağda çözünür olması ve yağ dokusunun fazla olması nedeniyle, aşırı kiloluluk durumunda vitamin $D$ 


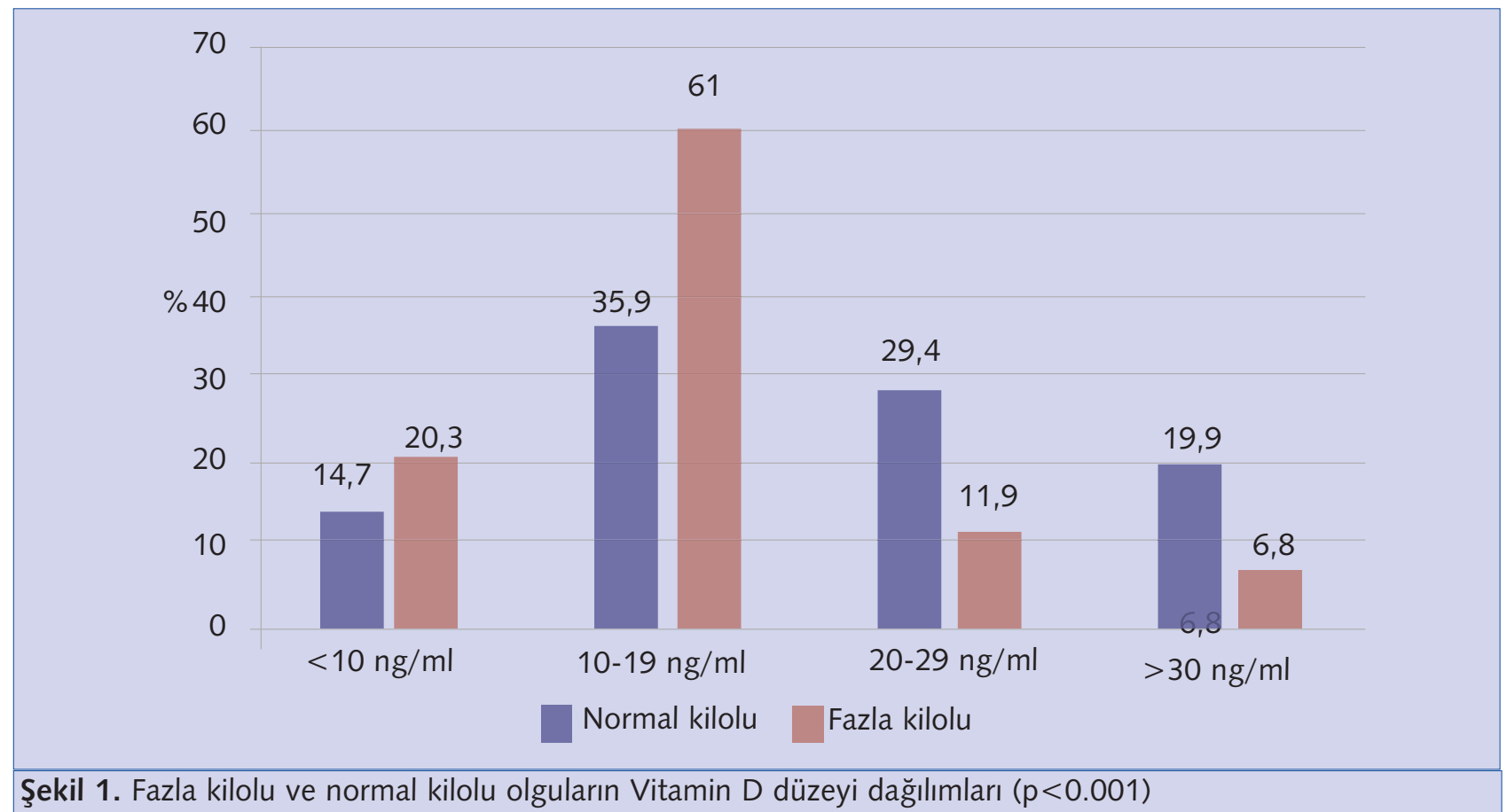

Şekil 1. Fazla kilolu ve normal kilolu olguların Vitamin D düzeyi dağılımları $(p<0.001)$

ihtiyacı artmaktadır (22). Yapılan bir çalışmada vitamin D eksikliği olan fazla kilolu çocukların vitamin D eksikliği tedavisinde normal kilolu çocuklara göre daha yüksek doz vitamin D gereksinimi olduğu gösterilmiştir (23). Obez ve fazla kilo riski olan çocuklarda vitamin D eksikliği tedavisi sonrasında,vitamin $\mathrm{D}$ düzeyleri ile ilgili çalışmalara gereksinim duyulmaktadır.

Çalışmamızda kan hemoglobin, serum ferritin ve vitamin B12 değerleri her iki grupta benzerdir. Demir eksikliği sıklığı normal kilolu grupta \%23. 9, fazla kilo riski olan grupta ise \% 30. 4'dür. Ferritin kilo fazlalığı riski olan çocuklarda demir durumundan ziyade inflamasyonun da bir göstergesi olduğundan altta yatan demir ve vitamin eksikliğini maskeleyebilmektedir (24). Çalışmamıza benzer biçimde, Gammon ve arkadaşlarının yaptıkları çalışmada yetişkinlerde vitamin B12 ile aşırı kilo ve kilo fazlalığı arasında herhangi bir ilişki gösterilememiştir (25). Yapılan bir çalışmada BKi'nin artması serum vitamin B12 eksikliği için bir risk olduğu, aşırı kilolu çocukların beslenme değerlendirmelerinin yapılmasının oldukça önemli olduğu belirtilmiştir (26).

Aşırı kilonun, çocuklarda hastaneye yatış gerektiren şiddetli alt solunum yolu enfeksiyonları üzerine etkisi hala tam olarak bilinmemektedir
(27). Bizim çalışmamızda fazla kilo riski olan çocuklarda normal kilolu çocuklara göre alt solunum yolu ve üst solunum yolu enfeksiyon sıklığının benzer oranda olduğu gösterildi. Çalışmamızda çalışmaya katılan çocukların serum $25(\mathrm{OH}) \mathrm{D}$ düzeyi ile eş zamanlı olarak serum kalsiyum, fosfor, alkalen fosfataz ve paratiroid hormon düzeylerinin değerlendirilmemesi sınırlama oluşturmaktadır. Diğer bir kısıtılık çalışmamızın tek merkezli çalışma olması ve olgu sayısının az olmasıdır. Fazla kilo riski olan çocuklarda serum $25(\mathrm{OH})$ D düzeyleri ile ilgili çok merkezli, olgu sayısının fazla olduğu, uzun süreli çalışmalar daha genel sonuçların elde edilmesi için gerekmektedir.

\section{Sonuç}

Bebek ve çocuklara gelişim döneminde demir ve vitamin $D$ takviyesi yapılması önemlidir. Ailelere yenidoğan döneminden itibaren bebek beslenmesi ile ilgili tutum oluşturacak eğitimler yapılmalıdır. Çocuklara her dönemde kol ve bacakları açık biçimde güneşle temas sağlayıcı açık hava aktiviteleri yaptırılmalıdır.

Çalışmamız fazla kilo riski olan çocuklarda serum $25(\mathrm{OH})$ D düzeyinin düşük olduğunu göstermektedir. Fazla kilo riski olan çocuklarda dengeli beslenmenin desteklenmesi ve vitamin D desteğinin sağlanması izlenmelidir. 


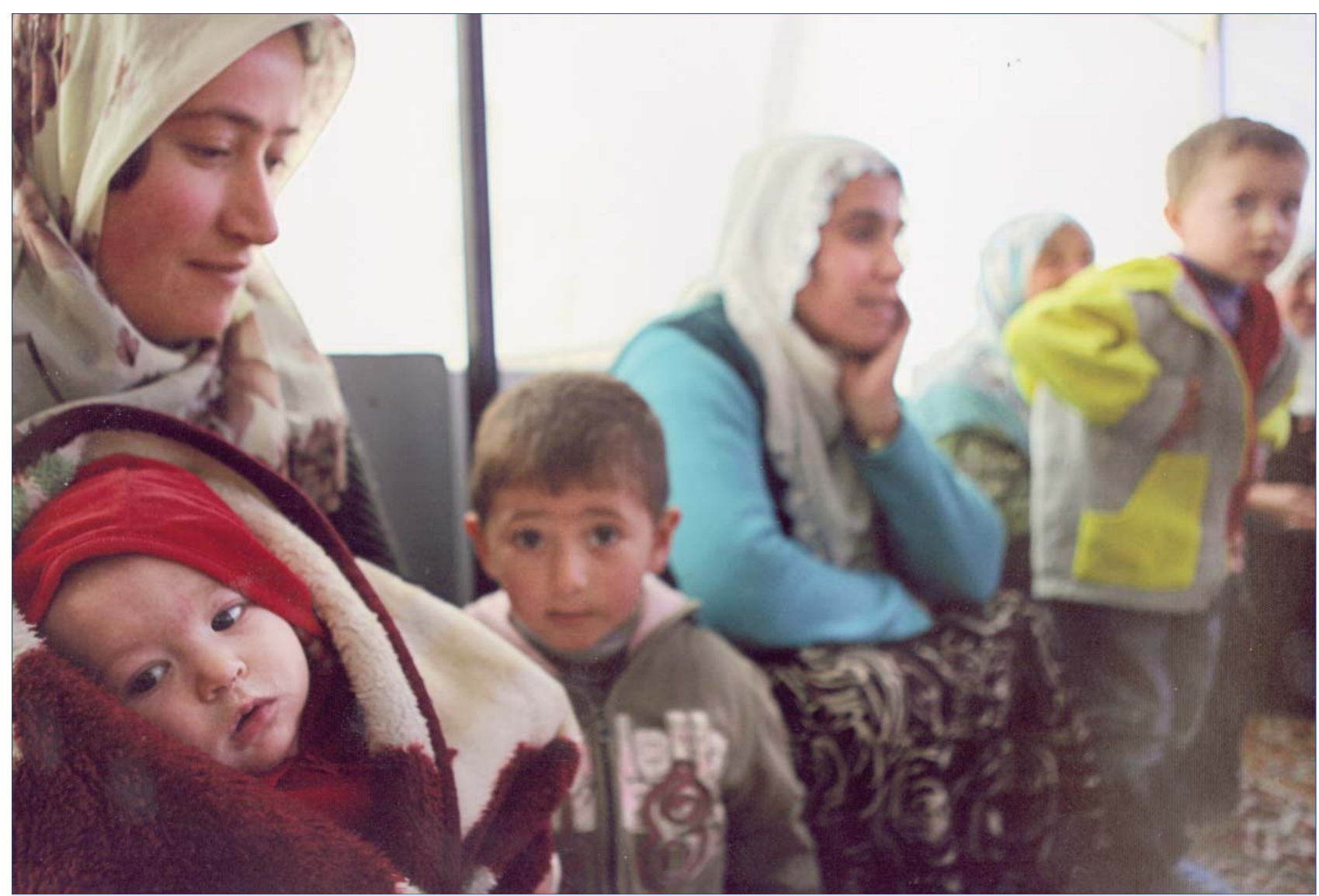

Fotoğraf: Dilek Eren TTB-STED Fotoğraf yarışması arşivinden

İletişim: Dr. Beril Aydın

E-posta: beril_ozdemir@yahoo.com

\section{Kaynaklar}

1. Holick MF. Vitamin D deficiency. N Engl J Med 2007;357:266-81.

2. Cassim R, Russell MA, Lodge CJ, Lowe AJ, Koplin $\mathrm{JJ}$, Dharmage SC. The role of circulating 25 hydroxyvitamin $D$ in asthma: Asystematicreview. Allergy 2015;70:339-54.

3. Pludowski P, Holick MF, Grant WB, Konstantynowicz J, Mascarenhas MR, Haq A, et al. Vitamin D supplementationguidelines. J SteroidBiochemMolBiol. 2018; 175:125-135. doi: 10. 1016/j. jsbmb. 2017. 01. 021.

4. Reis $A F$, Hauache $O M$, Velho $G$. Vitamin $D$ endocrinesystemandthegeneticsusceptibilitytodiabe tes, obesityandvasculardisease. A review of evidence. DiabetesMetab. 2005;31:318-25. 5) Hyppönen E, Power C. Vitamin D statusandglucosehomeostasis in the 1958 British birthcohort: the role of obesity. DiabetesCare 2006;29:2244-6.

6. VinhquocLu'o'ng K, Nguyen LTH. Thebeneficial role of vitamin $D$ in obesity: possiblegeneticandcellsignalingmechanisms. Nutr J 2013; 12: 89.
7. Mai X. M. ,Chen Y., Camargo C. A. , Jr. Crosssectionalandprospectivecohortstudy of serum 25 hydroxyvitamin D levelandobesity in adults: The HUNT study. Am. J. Epidemiol. 2012;175:10291036.

8. Plesner JL, Dahl M, Fonvig CE, Nielsen TRH, Kloppenborg JT, Pedersen O, Hansen T, Holm JC. Obesity is associatedwith vitamin $D$ deficiency in Danish children andadolescents. J Pediatr EndocrinolMetab. 2018 Jan 26;31 (1):53-61.

9. Saggese $G$, Vierucci $F$, Boot $A M$, et al. Vitamin $D$ in childhoodandadolescence: an expertpositionstatement. Eur J Pediatr 2015; 174 (5): 565-76.

10. World HealthOrganization. WHO Child GrowthStandards: length/height-for-age, weightfor-length, weight-for-heightand body massindexfor-age: methodsanddevelopment 2006. Geneva: WHO; 2006.

11. WHO MulticentreGrowth Reference StudyGroup. WHO Child GrowthStandardsbased on length/height, weightand age. ActaPaediatrSuppl 2006;450:76-85.

12. Holick MF, Binkley NC, Bischoff-Ferrari HA, Gordon CM, Hanley DA, Heaney RP, et al. Evaluation, treatment, andprevention of vitamin $\mathrm{D}$ deficiency: an 
EndocrineSocietyclinicalpracticeguideline. J

ClinEndocrinolMetab 2011;96:1911-30.

13. Atasoy $V$, Altunbaş EA, Set T. Fazla kilolu ve obez çocuklarda $D$ vitamini düzeylerinin değerlendirilmesi. Türk Aile HekDerg. 2019;23 (3):102-109.

14. Mengen E. Obez Çocuklarda D Vitamini Duzeylerinininsulin Direnci ve Hepatosteatoz ile İlişkisi. Türkiye Çocuk Hastalıkları Dergisi 2020;14 (1):36-41.

15. Cediel $G$, Corvalán $C$, López de Romaña $D$, Mericq V, Uauy R. Prepubertaladiposity, vitamin D status, andinsulinresistance. Pediatrics 2016;138 (1):e20160076.

16. Wortsman J. ,Matsuoka L. Y. , Chen T. C. , Lu Z. , Holick M. F. Decreasedbioavailability of vitamin D in obesity. Am. J. Clin. Nutr. 2000;72:690-693. doi: 10. 1093/ajcn/72. 3. 690.

17. Ding C, Gao D, Wilding J, Trayhurn P, Bing C. Vitamin $D$ signalling in adiposetissue. Br J Nutr. 2012;108:1915-23.

18. Kurşun ÖS. Şişman çocuklarda D vitamini düzeyleri ve insülin direnci ile ilişkisinin araştırılması (Uzmanlık Tezi). Edirne: Trakya Üniversitesi; 2008.

19. Florez $H$, Martinez R, Chacra W, Strickman-Stein $\mathrm{N}$, Levis $\mathrm{S}$. Outdoorexercisereducesthe risk of hypovitaminosis $\mathrm{D}$ in theobese. J SteroidBiochemMolBiol. 2007; 103:679-81.

20. Gazi Üniversitesi/Sağlık Bakanlığı (GÜ/SB), Türkiye'de 6-17 Aylık Çocuklarda ve Annelerinde Hemoglobin Ferritin D -Vitamini Düzeyi ve Demir Eksikliği Anemisi Durum Belirleme. Yürütülen Programların Değerlendirilmesi Araştırması Gazi Üniversitesi Tıp Fakültesi, Ankara: 2011: 106.

21.Yuzbashian $E$, Asghari $G$, Hedayati $M$, Zarkesh $M$, Mirmiran P, Khalaj A. Determinants of vitamin D receptor gene expression in visceralandsubcutaneousadiposetissue in nonobese, obese, andmorbidlyobesesubjects.

TheJournal of steroidbiochemistryandmolecularbiology. 2019;187:82-7.

22. Caron-Jobin M, Morisset AS, Tremblay A, Huot $C$, Légaré $D$, Tchernof $A$. Elevated serum $25(\mathrm{OH}) \mathrm{D}$ concentrations, vitamin $D$, andcalciumintakesareassociatedwithreducedadipocy te size in women. Obesity (Silver Spring) 2011;19:1335-41.

23. Chung IH, Kang YS, Yoo EG. Responseto vitamin $D$ replacement in overweightand normal weightchildrenwith vitamin $D$ deficiency. Annals of PediatricEndocrinology\&Metabolism 2019; 24:2226.

24. Lecube A. ,Hernández C. , Pelegrí D. , Simó R. Factorsaccountingforhighferritinlevels in obesity. International Journal of Obesity. 2008;32 (11):1665-1669. doi: 10. 1038/ijo. 2008. 154.

25. Gammon CS, vonHurst PR, Coad J, Kruger R, Stonehouse W. Vegetarianism, vitamin B12 status, andinsulinresistance in a group of predominantlyoverweight/obese South Asianwomen. Nutrition. 2012; 28: 20-4.

26. Gunanti IR, Marks GC, Al-Mamun A, Long KZ. Low serum vitamin $B$ -

12 , andfolateconcentrationsandlowthiaminandribofl avinintakesareinverselyassociatedwithgreateradiposi ty in MexicanAmericanchildren. J Nutr. 2014; 144: 2027-33.

27. Okubo Y, Nochioka K, Testa M. Theimpact of pediatricobesity on hospitalizedchildrenwithlowerrespiratorytractinfecti ons in the United States. TheClin. Respiratory J. 2018;12:4. 